\title{
How Do Advisors Influence Mergers and Acquisitions?: An Analysis of Acquisitions in Japan
}

\author{
Ja Seung KOO'
}

Received: May 06, 2020 Revised: May 17, 2020 Accepted: June 07, 2020

\begin{abstract}
The objective of this study is to examine the differentiated influence of sell-side advisors and buy-side advisors on mergers and acquisitions (M\&A). Unlike prior studies on M\&A advisors, the study addresses different roles of target and acquirer advisors, and explores their influences on the cumulative abnormal returns (CAR) and acquisition premiums with an empirical analysis of longitudinal data of M\&As conducted by Japanese listed firms except financial companies from 1995 to 2012. M\&A data were obtained from the Securities Data Corporation's (SDC) database, and the individual firm data were collected from the Nikkei Economic Electronic Databank System (NEEDS), which provides a wide range of corporate information including financial status, operational performance, and strategy. Using a sample of 452 cases for the CAR and 498 cases for the analysis of acquisition premiums, the empirical results support the hypotheses of the target advisor's positive association with CAR and acquirer advisor's positive association with acquisition premiums. The findings of this study indicate the target advisor's positive contribution to the success of acquisition process and performance, and acquirer advisor's negative influence on the deal progress. The study provides theoretical implications on M\&A research and practical insights into the investment banking industry.
\end{abstract}

Keywords : Acquisitions, Mergers and Acquisitions, M\&A, M\&A Advisors, Event Study

JEL Classification Code : G24, G34, G14, M10, M19

\section{Introduction}

Management literature has addressed mergers and acquisitions (M\&A) with many different points of view. Identifying antecedents for successful acquisitions has been one of the most popular topics of M\&A research, and it has been found that various factors influence acquisition performance and successful deal progress (Haleblian \& Finkelstein, 1999; King, Dalton, Daily, \& Covin, 2004; Koo, 2016a; Sheikh, Ahmed, Arshad, \& Shakeel, 2015). Recently, the academic attention has also focused on the internal and external stakeholders' influence on the deal

${ }^{1}$ First Author and Corresponding Author. Associate Professor, Faculty of Business Administration, Kyoto Sangyo University, Japan [Postal Address: Motoyama, Kamigamo, Kita-ku, Kyoto, 603-8555, Japan] Email: koo.academic@gmail.com

() Copyright: The Author(s)

This is an Open Access article distributed under the terms of the Creative Commons Attribution Non-Commercial License (http://Creativecommons.org/licenses/by-nc/4.0/) which permits unrestricted noncommercial use, distribution, and reproduction in any medium, provided the original work is properly cited. process and acquisition performance (Koo, 2016b; Waddock \& Graves, 2006). Among other stakeholders, many finance and economics studies have addressed M\&A advisors and their reputation's contribution to the wealth gains of deal participants and the deal completion probability (Kale, Kini, \& Ryan, 2003; Rau, 2000; Servaes \& Zenner, 1996).

However, few studies take notice of the sell-side and buy-side advisors' different roles in the deal process and their differentiated characteristics that influence the outcome of transactions. Thus, this study focuses on the differentiated influence of sell-side advisors and buy-side advisors on deal progress and acquisition performance. Unlike prior studies on M\&A advisors, the study addresses different roles of target and acquirer advisors and explores their influences on the cumulative abnormal returns (CAR) and acquisition premiums with an empirical analysis of longitudinal data of M\&As conducted by Japanese listed firms except financial companies from 1995 to 2012. The empirical results support the hypotheses of the target advisor's positive association with CAR and acquirer advisor's positive association with acquisition premiums. 


\section{Theory and Hypotheses}

The study focuses on the differentiated influence of sellside and buy-side M\&A advisors on the deal progress and examines their differentiated impact on the acquirer's CAR and acquisition premiums. I explore the positive influence of target firm advisors, while addressing the acquirer advisors' negative impact, through an empirical analysis of M\&As conducted by Japanese publicly listed companies.

\subsection{Mergers and Acquisitions Advisors}

An extensive literature has found various empirical evidence on the degree to which the M\&A advisor is associated with successful deal execution. Bowers and Miller (1990) addressed the relationship between the capital market response and the choice of M\&A advisor and found that hiring a first-tier investment bank brings the total wealth gains to both acquirer and target shareholders. However, they also found no evidence that top-tier investment banks allow greater bargaining power during the negotiation process. Likewise, Servaes and Zenner (1996) were not able to find any relation between shareholder wealth and the tier of its M\&A advisor.

From the transaction costs perspective, rather than executing M\&A deals in-house, using professional advisory services incurs lower costs than focal firms, and investment banks reduce the information asymmetry between bidder and target firms (Servaes \& Zenner, 1996). M\&A advisors' services in mergers and acquisitions include the capability to detect better targets and acquirers, the ability to design a deal structure that allows more synergies, and the capability to provide comprehensive advice to focal firms to enhance the client's share of total wealth gain through M\&A (Kale et al., 2003). For various purposes, the bidder and the target firms hire M\&A advisors, but the roles and responsibilities of sellside and buy-side advisors are slightly different. Golubov, Petmezas, and Travlos (2012) pointed out that bidders are more likely to hire M\&A advisors when the deal is complex and if acquirers have less acquisition experience. The role of buy-side advisors in the M\&A process is broader compared to the sell-side advisors' role. Target advisors need to address the preliminary stage of strategic decisions of focal firms, and finish their work at the end of closing the deal. Acquirer advisors, however, start engaging in the process relatively later, but they need to take care of the bidders' circumstances including shareholder wealth after the deal is closed.

Considering the early engagement of target advisors in the deal process, the contribution to the progress of the M\&A is relatively obvious. The criteria for searching for potential buyers are also likely simple and clear. Moreover, since the responsibility is almost complete at the closing of the deal, there are less arguments on the fee payment and work leftover. By having a clear understanding of the roles and responsibilities of advisors, target advisors will be able to contribute to the deal progress and outcome more positively. Thus, the first hypothesis is proposed:

Hypothesis 1: When the target firm has $M \& A$ advisors, the CAR increases and the acquisition premium decreases.

On the other hand, acquirer advisors are hired to resolve more complex issues in the deal progress, as Golubov et al. (2012) posited earlier in their study. Unlike target advisors, acquirer advisors are invited to the deal process relatively late, and there could be many problematic issues that the acquirer's internal team was not able to address. Although they are engaged late in the process, acquirer advisors should understand the strategic goals of the deal, and they are expected to deliver value for their clients, including strategic advice on the potential synergy gains and post-acquisition performance. Therefore, acquirer advisors would encounter a more challenging deal environment and cover a wider range of responsibilities than target advisors. Taking on complex issues with less understanding of the deal, and covering a wider span of work could be associated with negative outcomes of deal progress and acquisition performance. Thus, the second hypothesis is proposed:

Hypothesis 2: If the acquirer firm has $M \& A$ advisors, the $C A R$ decreases, and the acquisition premium increases.

\section{Methodology}

\subsection{Sample and Data Collection}

The study carries out an empirical analysis by using M\&A data of Japanese public companies from 1995 to 2012. During this period of the Lost 20 Years in Japan, many corporate transactions occurred including mergers and acquisitions due to the transformation of business portfolios following the Japanese asset price bubble's collapse in the early 1990s (Anderson, 2016; Han, Reinhart, \& Shin, 2018). It allows enough samples of mergers and acquisitions for empirical tests.

This study yields a sample of 452 cases for the CAR and 498 cases for the analysis of acquisition premiums. Companies in the financial industry were excluded to avoid any potential distortion of empirical analysis from regulatory obligations. I also sampled the cases of M\&As where the acquirer took more than 50 percent of target shares (Moeller, Schlingemann, \& Stulz, 2005).

M\&A data were obtained from the Securities Data Corporation's (SDC) database. It allows access to detailed information of corporate transactions conducted internationally and domestically. Many economics and 
management studies use the SDC database because of its broad coverage of corporate transactions including mergers and acquisitions, and alliances (Schilling, 2009). I collected the individual firm data from the Nikkei Economic Electronic Databank System (NEEDS), which provides a wide range of corporate information including financial status, operational performance, and strategy.

\subsection{Variables and Measures}

Dependent variables. The study adopts two dependent variables of CAR: the acquirer and the acquisition premiums. The event window of the CAR was $[-1,0]$. This event window was selected to avoid the possible confounding effects from the longer-term market response, which is not causally related to the acquisition (McWilliams \& Siegel, 1997).

Following the event study methodology using CAR to measure the influence of acquisition announcement on stock price (McWilliams \& Siegel, 1997), the study adopted the ordinary least squares (OLS) estimation as follows:

$$
R_{i t}=\alpha_{i}+\beta_{i} \times R_{m t}+\varepsilon_{i t}
$$

where $i$ represents the firms, $t$ indexes days, $\mathrm{R}_{\mathrm{it}}$ is the rate of return on the stock price of firm $i$ on day $t ; \mathrm{R}_{\mathrm{mt}}$ is the rate of return on Nikkei 225, a stock market index for the Tokyo Stock Exchange drawn from 225 publicly owned companies in Japan, on day $t ; \alpha$ is the intercept term; $\beta$ is the systematic risk of stock $i$; and $\varepsilon_{\mathrm{it}}$ is the error term with $\mathrm{E}\left(\varepsilon_{\mathrm{it}}\right)=0$. The estimation period for this model is 150 days, that is, from 200 to 51 trading days prior to acquisition announcements (Chatterjee, 1991).

Then, the return on the stock of firm $i$ on day $t$ was estimated as follows:

$$
\widehat{R}_{i t}=\alpha_{i}+\beta_{i} \times R_{m t}
$$

where $\alpha$ and $\beta$ are the OLS parameters.

Accordingly, the abnormal return of firm $i$ is calculated as follows:

$$
A R_{i t}=R_{i t}-\widehat{R}_{i t}
$$

The CAR is then calculated by adding up the abnormal returns from day -1 to the day of announcement. As Arikan and Capron (2010) conducted, I used the shortest event window of ' -1 to 0 ' trading days, considering the maturity of capital market in Japan.

The acquisition premium was originally an economic term used mainly for capital market dynamics for M\&As (Laamanen, 2007), although it has a high value that other measures do not capture, such as the likelihood of acquisition completion threatened by various deal breaking factors. This study regards the acquisition premium as an additional cost incurred by the acquirer to close the deal, which could be negatively associated with the M\&A advisor's positive contribution to the deal progress and vice versa. It is measured by taking the difference between the price of acquirer paid per share and the target firm's stock price on the day prior to the announcement of the acquirer's bid.

Independent variables. The Target Advisor Dummy takes the value of 1 if the target firm hired more than 1 M\&A advisor, and 0 otherwise. The Acquirer Advisor Dummy also codes 1 if the acquirer firm had more than one M\&A advisor, and 0 otherwise.

Control variables. I included several deal-specific and firm-specific control variables that have been adopted by previous researches on M\&A. To control for the firmlevel operating conditions, I used the acquiring and target firm's return on equity (ROE) of the previous year of the acquisition announcement based on data from the Nikkei NEEDS. The logarithm of transaction value from SDC database was measured to control for the deal size. To control for the similarity of acquirer and target industry, I included an industry relatedness dummy variable based on the firm's primary four-digit of the Standard Industry Classification (SIC) code by taking 1 for both the acquiring and the target firms' SIC code being identical (Hill \& Hoskisson, 1987; Markides \& Ittner, 1994). Payment method for the transaction was controlled by using a dummy variable that equals 1 if more than 50 percent of payment was made by cash (Fuller, Netter, \& Stegemoller, 2002). To control for the competitive conditions of the deal process, I included a competing bidder dummy variable that takes 1 for the presence of more than two bidders (Puranam, Powell, \& Singh, 2006; Schweiger, 2002). Following prior literature (Haleblian \& Finkelstein, 1999; Haspeslagh \& Jemison, 1991), acquisition experience of the acquiring firm was controlled by measuring the number of acquisitions over the previous three years. I also controlled for the complexity of cross-border acquisition by including a binary measure code - 1 if the transaction is a cross-border deal (Schweiger, 2002). Other than those above, controls for the rumor and the fiscal year were included as indicator variables.

Model specification. To illustrate the differentiated impact of acquiring and target firm M\&A advisors on the merger and acquisition, the study adopted two dependent variables of CAR and acquisition premium. Thus, the two hypotheses were tested in the following OLS regression models:

$$
\begin{aligned}
& C A R_{i t}=\alpha_{t}+X_{i t} \beta+\varepsilon_{i t} \\
& A P_{i t}=\alpha_{t}+X_{i t} \beta+\varepsilon_{i t}
\end{aligned}
$$


where $X$ is a vector of independent variables, $i$ indexes the acquiring firms, $t$ indexes Japanese fiscal years, and $\boldsymbol{\varepsilon}_{\text {it }}$ denotes error term.

\section{Results}

Table 1 illustrates the results of the OLS regression model that estimates the differentiated effects of acquiring and target firm M\&A advisors on the CAR. Model 1 is a baseline estimation with control variables only. The coefficients of Acquirer's Operating Performance ( $b=$ -0.02, se $=0.00, p<0.01)$, Payment Method $(b=-0.01$, se $=$ $0.01, p<0.05)$, Competing Bidder $(b=-0.02, s e=0.01, p<$ $0.01)$, and Rumor $(b=-0.02$, se $=0.01, p<0.10)$ are negative and significant. Model 2 includes Target Advisor Dummy and Acquirer Advisor Dummy to the baseline estimation. The regression coefficient for Target Advisor Dummy is positive and statistically significant $(b=0.02, s e=0.01, p$ $<0.05$ ) while that of Acquirer Advisor Dummy is negative and insignificant $(b=-0.01$, se $=0.01, n . s$. $)$. This result is consistent with the prediction of Hypothesis 1. In Models 3 and 4, I estimate the influence of target and acquirer firm advisor separately. Consistent with the result of Model 1, the coefficient of Target Advisor Dummy is positive and significant $(b=0.02$, se $=0.01, p<0.05)$ in Model 3, while Acquirer Advisor Dummy shows negative and not statistically significant coefficient $(b=-0.01, s e=0.01, n . s$. $)$ in Model 4 .

Table 2 indicates the estimation results using the acquisition premium as the dependent variable. Model 1 contains only the control variables. Transaction Value $(b=$ $0.04, s e=0.01, p<0.01)$ and Rumor $(b=-0.20$, se $=0.07$, $p<0.01)$ are statistically significant. Model 2 tests both hypotheses predicting target advisor's negative association with the acquisition premium and acquirer advisor's positive

Table 1: Result of regression analysis of cumulative abnormal returns

\begin{tabular}{|c|c|c|c|c|c|}
\hline \multirow{2}{*}{\multicolumn{2}{|c|}{ Variables }} & \multicolumn{4}{|c|}{ Cumulative Abnormal Return $(-1,0)$} \\
\hline & & Model 1 & Model 2 & Model 3 & Model 4 \\
\hline$H 1$ & Target Advisor Dummy & & $\begin{array}{c}0.02^{*} \\
(0.01)\end{array}$ & $\begin{array}{l}0.02^{*} \\
(0.01)\end{array}$ & \\
\hline$H 2$ & Acquirer Advisor Dummy & & $\begin{array}{l}-0.01 \\
(0.01)\end{array}$ & & $\begin{array}{l}-0.00 \\
(0.01)\end{array}$ \\
\hline & Acquirer's Operating Performance (ROE) & $\begin{array}{c}-0.02^{* *} \\
(0.00)\end{array}$ & $\begin{array}{c}-0.02^{* *} \\
(0.00)\end{array}$ & $\begin{array}{c}-0.02^{* *} \\
(0.00)\end{array}$ & $\begin{array}{c}-0.02^{* *} \\
(0.00)\end{array}$ \\
\hline & Target's Operating Performance (ROE) & $\begin{array}{c}0.00 \\
(0.00)\end{array}$ & $\begin{array}{c}0.00 \\
(0.00)\end{array}$ & $\begin{array}{c}0.00 \\
(0.00)\end{array}$ & $\begin{array}{c}0.00 \\
(0.00)\end{array}$ \\
\hline & Transaction Value & $\begin{array}{c}0.00 \\
(0.00)\end{array}$ & $\begin{array}{c}0.00 \\
(0.00)\end{array}$ & $\begin{array}{c}0.00 \\
(0.00)\end{array}$ & $\begin{array}{c}0.00 \\
(0.00)\end{array}$ \\
\hline & Industry Relatedness & $\begin{array}{c}0.01 \\
(0.01) \\
\end{array}$ & $\begin{array}{c}0.01 \\
(0.01) \\
\end{array}$ & $\begin{array}{c}0.01 \\
(0.01) \\
\end{array}$ & $\begin{array}{c}0.01 \\
(0.01) \\
\end{array}$ \\
\hline & Payment Method & $\begin{array}{l}-0.01^{*} \\
(0.01)\end{array}$ & $\begin{array}{l}-0.01 \\
(0.01)\end{array}$ & $\begin{array}{l}-0.01 \\
(0.01)\end{array}$ & $\begin{array}{l}-0.01 \dagger \\
(0.01)\end{array}$ \\
\hline & Competing Bidder & $\begin{array}{c}-0.02^{* *} \\
(0.01)\end{array}$ & $\begin{array}{c}-0.03^{* *} \\
(0.01)\end{array}$ & $\begin{array}{c}-0.03^{\star *} \\
(0.01)\end{array}$ & $\begin{array}{c}-0.02^{* *} \\
(0.01)\end{array}$ \\
\hline & Acquisition Experience & $\begin{array}{c}0.00 \\
(0.00)\end{array}$ & $\begin{array}{c}0.00 \\
(0.00)\end{array}$ & $\begin{array}{c}0.00 \\
(0.00)\end{array}$ & $\begin{array}{c}0.00 \\
(0.00)\end{array}$ \\
\hline & Cross Border & $\begin{array}{l}-0.02 \\
(0.03)\end{array}$ & $\begin{array}{l}-0.01 \\
(0.03)\end{array}$ & $\begin{array}{l}-0.01 \\
(0.03)\end{array}$ & $\begin{array}{l}-0.01 \\
(0.03)\end{array}$ \\
\hline & Rumor & $\begin{array}{c}-0.02 \dagger \\
(0.01)\end{array}$ & $\begin{array}{c}-0.01 \dagger \\
(0.01)\end{array}$ & $\begin{array}{l}-0.01 \dagger \\
(0.01)\end{array}$ & $\begin{array}{c}-0.02 \dagger \\
(0.01)\end{array}$ \\
\hline & Fiscal Year & Yes & Yes & Yes & Yes \\
\hline & Intercept & $\begin{array}{l}-0.01 \\
(0.02) \\
\end{array}$ & $\begin{array}{l}-0.00 \\
(0.02)\end{array}$ & $\begin{array}{l}-0.00 \\
(0.02)\end{array}$ & $\begin{array}{l}-0.01 \\
(0.02)\end{array}$ \\
\hline & $\mathrm{R}^{2}$ & 0.1 & 0.11 & 0.11 & 0.1 \\
\hline
\end{tabular}

Note: $\uparrow$ for $p<0.10,{ }^{*}$ for $p<0.05$, and ${ }^{* *}$ for $p<0.01$. One-tailed test. Robust standard errors are in parentheses. $n=452$. 
impact on the acquisition premium. In Models 3 and 4, they are separately estimated. Consistent with Hypothesis 2, the coefficient of Acquirer Advisory Dummy is positive and statistically significant in Model $2(b=0.16$, se $=0.05, p<$ $0.01)$ and Model $4(b=0.16$, se $=0.04, p<0.01)$. By using acquisition premium as the dependent variable, the acquirer advisor's negative influence on the deal progress is distinctly observed, thus supporting hypothesis 2 .

\section{Conclusion and Discussions}

This paper started with the question of how M\&A advisors influence the acquisition process and performance. Using a sample of 452 acquisitions for CAR and 498 acquisitions for acquisition premium conducted by Japanese public firms excluding those in the financial industry, this study conducted empirical research to answer the question.
The major findings of this paper can be summarized as follows. First, the existence of a target advisor leads to an acquirer's positive abnormal return. This finding corroborates the initial prediction that the target side advisor is expected to be positively associated with acquisition performance. Traditionally, the M\&A deal starts a substantial transaction process from the intention of the sell-side rather than from the buy-side. Appointing an M\&A advisor on the sell-side would be translated as a 'go' signal to start the deal process, and would reflect the seller's earnest intention. Certain sellside firms on the other hand, passively correspond to potential buyers' initial proposal without hiring advisors. The lead advisor of the target company represents the overall sell-side firm's interest, but the advisor needs to be transparent when responding to the request to provide various financial and strategic information during the due diligence process, and is expected to be the coordinator for more effective and faster

Table 2: Result of regression analysis of acquisition premiums

\begin{tabular}{|c|c|c|c|c|c|}
\hline \multirow{2}{*}{\multicolumn{2}{|c|}{ Variables }} & \multicolumn{4}{|c|}{ Acquisition Premium (1 day) } \\
\hline & & \multirow[t]{2}{*}{ Model 1} & \multirow{2}{*}{$\begin{array}{c}\text { Model } 2 \\
-0.00 \\
(0.06)\end{array}$} & \multirow{2}{*}{$\begin{array}{c}\text { Model } 3 \\
0.06 \\
(0.05)\end{array}$} & \multirow[t]{2}{*}{ Model 4} \\
\hline$H 1$ & Target Advisor Dummy & & & & \\
\hline$H 2$ & Acquirer Advisor Dummy & & $\begin{array}{l}0.16^{* *} \\
(0.05) \\
\end{array}$ & & $\begin{array}{l}0.16^{* *} \\
(0.04)\end{array}$ \\
\hline & Acquirer's Operating Performance (ROE) & $\begin{array}{l}-0.00 \\
(0.01) \\
\end{array}$ & $\begin{array}{l}-0.02 \\
(0.01) \\
\end{array}$ & $\begin{array}{l}-0.01 \\
(0.02) \\
\end{array}$ & $\begin{array}{l}-0.02 \\
(0.01) \\
\end{array}$ \\
\hline & Target's Operating Performance (ROE) & $\begin{array}{c}0.00 \\
(0.00)\end{array}$ & $\begin{array}{c}0.00 \\
(0.01)\end{array}$ & $\begin{array}{c}0.00 \\
(0.00)\end{array}$ & $\begin{array}{c}0.00 \\
(0.01)\end{array}$ \\
\hline & Transaction Value & $\begin{array}{l}0.04^{* *} \\
(0.01)\end{array}$ & $\begin{array}{l}0.04^{* *} \\
(0.01)\end{array}$ & $\begin{array}{l}0.04^{* *} \\
(0.01)\end{array}$ & $\begin{array}{l}0.04^{* *} \\
(0.01)\end{array}$ \\
\hline & Industry Relatedness & $\begin{array}{l}-0.03 \\
(0.04) \\
\end{array}$ & $\begin{array}{l}-0.03 \\
(0.04) \\
\end{array}$ & $\begin{array}{l}-0.03 \\
(0.04) \\
\end{array}$ & $\begin{array}{l}-0.03 \\
(0.04) \\
\end{array}$ \\
\hline & Payment Method & $\begin{array}{c}0.05 \\
(0.04) \\
\end{array}$ & $\begin{array}{c}0.07 \\
(0.05) \\
\end{array}$ & $\begin{array}{c}0.07 \\
(0.05) \\
\end{array}$ & $\begin{array}{l}0.07 \dagger \\
(0.04) \\
\end{array}$ \\
\hline & Competing Bidder & $\begin{array}{l}-0.02 \\
(0.05)\end{array}$ & $\begin{array}{l}-0.04 \\
(0.05)\end{array}$ & $\begin{array}{l}-0.04 \\
(0.05)\end{array}$ & $\begin{array}{l}-0.04 \\
(0.05)\end{array}$ \\
\hline & Acquisition Experience & $\begin{array}{l}-0.01 \\
(0.02)\end{array}$ & $\begin{array}{l}-0.00 \\
(0.02)\end{array}$ & $\begin{array}{l}-0.01 \\
(0.02)\end{array}$ & $\begin{array}{l}-0.00 \\
(0.02)\end{array}$ \\
\hline & Cross Border & $\begin{array}{l}-0.21 \\
(0.17) \\
\end{array}$ & $\begin{array}{l}-0.19 \\
(0.19) \\
\end{array}$ & $\begin{array}{l}-0.19 \\
(0.17) \\
\end{array}$ & $\begin{array}{l}-0.19 \\
(0.19)\end{array}$ \\
\hline & Rumor & $\begin{array}{c}-0.20 * * \\
(0.07)\end{array}$ & $\begin{array}{c}-0.19^{* *} \\
(0.07)\end{array}$ & $\begin{array}{c}-0.19^{* *} \\
(0.07)\end{array}$ & $\begin{array}{c}-0.19 * * \\
(0.07)\end{array}$ \\
\hline & Fiscal Year & Yes & Yes & Yes & Yes \\
\hline & Intercept & $\begin{array}{l}-0.08 \\
(0.08)\end{array}$ & $\begin{array}{l}-0.01 \\
(0.09)\end{array}$ & $\begin{array}{l}-0.05 \\
(0.09)\end{array}$ & $\begin{array}{l}-0.01 \\
(0.08)\end{array}$ \\
\hline & $\mathrm{R}^{2}$ & 0.17 & 0.19 & 0.18 & 0.19 \\
\hline
\end{tabular}

Note: $\uparrow$ for $p<0.10,{ }^{*}$ for $p<0.05$, and ${ }^{* *}$ for $p<0.01$. One-tailed test. Robust standard errors are in parentheses. $n=498$. 
communication in the negotiation process. Thus, the capital market would be able to regard the participation of the target advisor in the deal process as a positive sign for the success of the acquisition process and performance.

Second, the analysis shows that the existence of a buyside advisor leads to additional burdens of the acquisition premium, which would be interpreted as having a negative influence on the deal progress. The strategic choice between 'make' or 'buy' is normally decided by the side that is using up financial resources. Therefore, in the case of M\&A, the final decision to confirm and execute the transaction should normally be made by the buy-side. There should be intense internal discussions on the advantages and disadvantages of the proposed transaction. Although there is a common understating of the strategic rationale of the deal, there should be a party still opposing the transaction. Additional groups can join the opposing side of the transaction after finding a negative aspect of the proposed transaction. Thus, appointing M\&A advisors from buy-side firms not only means that the firm wants to have more professional support from lead advisors, but also that they have an internal disagreement on the proposed acquisition. It can also mean that they have a relatively insufficient understanding of the target firm's business or industry. Consequently, the existence of an acquirer advisor would be regarded as being negatively associated with deal progress.

This study has several theoretical and practical implications. In terms of theory, this study successfully demonstrates the differentiated influence of M\&A advisors on their clients' M\&A deal progress. Although the M\&A advisors' roles and influence on the deal progress and the success of the M\&A seem similar regardless of the type of clients, this study shows that sell-side and buy-side advisors' responsibility and their practical influence are substantially different. The study focuses and provides empirical support for the differentiated role of M\&A advisors, which were not previously regarded as influential factors in management research.

For practitioners, especially for the client firm, the results of this study provide meaningful insight if they want to hire M\&A advisors. The client firms of the M\&A advisors should pay more attention to the circumstances they are surrounded by, and should carefully consider choosing appropriate advisors.

\section{References}

Anderson, R. G. (2016). Japan's Economic Performance "Lost Decade": Myth, Reality, or Role Model? Journal of Asian Finance, Economics and Business, 3(1), 15-32. https://doi. org/10.13106/jafeb.2016.vol3.no1.15.

Arikan, A. M., \& Capron, L. (2010). Do newly public acquirers benefit or suffer from their pre-IPO affiliations with underwriters and VCs? Strategic Management Journal, 31(12), 1257-1289.
Bowers, H., \& Miller, R. (1990). Choice of investment banker and shareholders' wealth of firms involved in acquisitions. Financial Management, 19, 34-44.

Chatterjee, S. (1991). Gains in vertical acquisitions and market power: theory and evidence. Academy of Management Journal, 34(2), 436-448.

Fuller, K., Netter, J., \& Stegemoller, M. (2002). What do returns to acquiring firms tell us? Evidence from firms that make many acquisitions. The Journal of Finance, 57(4), 1763-1793.

Golubov, A., Petmezas, D., \& Travlos, N. G. (2012). When It Pays to Pay Your Investment Banker: New Evidence on the Role of Financial Advisors in M\&As. The Journal of Finance, 67(1), 271-311.

Haleblian, J., \& Finkelstein, S. (1999). The influence of organizational acquisition experience on acquisition performance: a behavioral learning perspective. Administrative Science Quarterly, 44(1), 29-56.

Han, S. H., Reinhart, W. J., \& Shin, Y. S. (2018). Influence of Global versus Local Rating Agencies to Japanese Financial Firms. Journal of Asian Finance, Economics and Business, 5(4), 9-20. http://doi.org/10.13106/jafeb.2018.vol5.no4.9

Haspeslagh, P. C., \& Jemison, D. B. (1991). Managing Acquisitions: Creating Value through Corporate Renewal. New York, NY: Free Press.

Hill, C. W., \& Hoskisson, R. E. (1987). Strategy and structure in the multiproduct firm. Academy of Management Review, 12(2), 331-341.

Kale, J. R., Kini, O., \& Ryan, H. E. (2003). Financial advisors and shareholder wealth gains in corporate takeovers. Journal of Financial and Quantitative Analysis, 38(3), 475-501.

King, D., Dalton, D., Daily, C., \& Covin, J. (2004). Meta-analyses of post-acquisition performance: Indications of unidentified moderators. Strategic Management Journal, 25(2), 187-200.

Koo, J. S. (2016a). How the lender-borrower relationship influences M\&As: An analysis of a strategic action in Japan. Journal of Distribution Science, 14(8), 101-107.

Koo, J. S. (2016b.) Stakeholders' Influence on Mergers and Acquisitions: A Research Review and Complementary Research Design. Kobe International University Economic and Management Review, 36, 1-20.

Laamanen, T. (2007). On the role of acquisition premium in acquisition research. Strategic Management Journal, 28(13), 1359-1369.

Markides, C. C., \& Ittner, C. D. (1994). Shareholder benefits from corporate international diversification: evidence from U.S. international acquisitions. Journal of International Business Studies, 25, 343-366.

McWilliams, A., \& Siegel, D. (1997). Event studies in management research: theoretical and empirical issues. Academy of Management Journal, 40(3), 626-657.

Moeller, S. B., Schlingemann, F. P., \& Stulz, R. M. (2005). Wealth destruction on a massive scale? A study of acquiring-firm 
returns in the recent merger wave. The Journal of Finance, $60(2), 757-782$.

Puranam, P., Powell, B. C., \& Singh, H. (2006). Due diligence as a signal detection problem. Strategic Organization, 4(4), 319-348.

Rau, P. R. (2000). Investment bank market share, contingent fee payments and the performance of acquiring firms. Journal of Financial Economics, 56, 293-324.

Schilling, M.A. (2009). Understanding the alliance data. Strategic Management Journal, 30(3), 233-260.

Schweiger, D. M. (2002). M\&A Integration: A Framework for Executives and Managers. New York, US: McGraw-Hill.
Servaes, H., \& Zenner, M. (1996). The role of investment banks in acquisitions. Review of Financial Studies, 9, 787-815.

Sheikh, M. J., Ahmed, M., Arshad, Q., \& Shakeel, W. (2015). Mergers and Acquisitions as Vital Instruments of Corporate Strategy: Current and Historical Perspective. Journal of Asian Finance, Economics and Business, 2(1), 15-21. https://doi. org/10.13106/jafeb.2015.vol2.no1.15.

Waddock, S., \& Graves, S. B. (2006). The impact of mergers and acquisitions on corporate stakeholder practices. Journal of Corporate Citizenship, 22, 91-108. 